\title{
COMPETITIVENESS IN THE EUROPEAN UNION: A TREND TO CONVERGENCE?
}

\author{
[Konkurenceschopnost v Evropské unii: trend ke konvergenci?] \\ Pavlína Balcarová ${ }^{1}$ \\ ${ }^{1}$ Mendelova univerzita v Brně, Provozně ekonomická fakulta, Zemědělská 1, 61300 Brno \\ Email: pavlina.balcarova@mendelu.cz
}

\begin{abstract}
The contribution verifies, whether the competitiveness of the European Union economies tends to converge or diverge. The competitiveness of a country is defined as the ability to create innovations. Innovations represent an important resource of the qualitative competitive advantage, which is crucial for sustainable competitiveness in the long term. We observed the composite indicator development in the time period 2000-2012 with focus on the trend dissimilarities in the European Union. We used a cluster analysis and beta and sigma convergence methods to the convergence/divergence tendency verification. The results of all three methods confirmed the converging trend of competitiveness in the European Union. We found out that initially less competitive economies are catching up with initially more competitive countries and the competitiveness of individual countries as well as the EU as a whole increase at the same time.
\end{abstract}

Keywords: beta convergence, cluster analysis, European Union, homogeneity, innovation, national competitiveness, sigma convergence, technology.

JEL classification: F62, O32, O52

Doručeno redakci: 15.2.2016; Recenzováno: 28.2.2016; 4.3.2016; Schváleno k publikování: 26.5.2016

\section{Introduction}

The convergence process has been in the center of attention of economists for a long time. Especially in the last decades the increasing economic integration and globalization have required increasing homogeneity in several areas. The importance of increasing homogeneity and thus the converging tendency of the EU member states is often stressed after the EU enlargements in 2004, 2007 and 2013 (see for example Malý, 2014 or Dostálová, 2014). There are many fiscal as well as monetary indicators, where convergence is desirable for further common development of the European Union as well as for enhancing its position in comparison with other developed countries. Most often the indicators of gross domestic product per head or real income per head are applied to the real convergence analysis (for example Martín et al., 2001, Žd'árek and Šindel, 2007, Halmai and Vásáry, 2010, Dobrinsky and Havlik, 2014 or ECB, 2015). Another group of authors is engaged in the nominal convergence analysis and monitor comparative price levels, interest rates or inflation rates development (de Grauwe and Schnabl, 2005, Hein and Truger, 2002, Žd'árek and Šindel, 2007, Barbosa and Alves, 2011 or Groll and van Roye, 2011). However the available results obviously do not confirm the converging trend in the European Union (among others for example Hein and Truger, 2002, Marelli and Signorelli, 2010, Barbosa and Alves, 2011, Groll and van Roye, 2011 or Brunet, 2013). Some authors also verify the convergence of competitiveness in the European Union, as competitiveness has been a well monitored indicator of countries performance in the last decades (Barbosa and Alves, 2011, Estrada et al., 2012 or Malý, 2014).

Although the competitiveness of the economy is carefully monitored by both policy makers and economists, it is still ambiguous, with reference to its exact meaning. It is possible to perceive the competitiveness of a country as its ability to compete with low prices or as an 
export performance of a country. Yet the meaning of this term is much broader. In this contribution we shall define competitiveness as an ability of the country to create innovations, as innovations represent the important resource of the qualitative competitive advantage, which is crucial for sustainable competitiveness in the long term. This attitude to the competitiveness of an economy was introduced by Fagerberg, Srholec and Knell (2004) and was called technology competitiveness. According to Fagerberg, Srholec and Knell (2004, p. 15), technology competitiveness means "the ability to compete successfully in markets for new goods and services". For the technology competitiveness evaluation we use a set of variables suggested by Fagerberg, Srholec and Knell (2004, 2005 and 2007), but the choice of the individual indicators is adjusted to the European Union economies, as it is described in the next section (Methodology and Data). The common feature of all these indicators is their importance for the smart growth of economy, which is one of the priorities of the European Union in this decade (the EU strategy Europe 2020 puts forward three main priorities for the time period 2010-2020, which are smart, sustainable and inclusive growth, for more information see the European Commission, 2010).

The main goal of the contribution is to verify, whether technology competitiveness in the European Union tends to converge or diverge. As long as the converging tendency is not unambiguously confirmed, the second goal will be to identify the group of countries, which create a barrier for an increasing homogeneity in the EU (according to the technology competitiveness variables). For assessing the converging or diverging tendency of technology competitiveness primarily the method of the cluster analysis will be used. The results will be verified by the beta and sigma convergence analysis.

In the next part the indicators of technology competitiveness are described along with the method of the cluster analysis and its application for the convergence analysis explained. Then the results of the cluster analysis are presented, the convergence/divergence tendency is identified and the barriers of the EU homogeneity increase are searched. The results of the cluster analysis are compared with traditionally used methods of the convergence analysis, i.e. the beta and sigma convergence. The main conclusions are summarized in the last section.

\section{Methodology and data}

The selection of the indicators of technological competitiveness comes out the work of Fagerberg, Srholec and Knell (2004, 2005 and 2007), who distinguished four aspects of national competitiveness (technology, capacity, price and demand). In this paper we focus on technology competitiveness, which is especially important, as it reflects the ability of a country to create a qualitative competitive advantage based on innovations. According to Fagerberg, Srholec and Knell (2004) technology competitiveness has three dimensions. The first one covers the indicators of science and technology inputs (S\&T inputs), the second one is created by the indicators of science and technology outputs (S\&T outputs) and the last dimension testifies about the national level of the ICT infrastructure. In their original approach the authors assessed the competitiveness of a broad sample of countries out of the whole world, i.e. countries at markedly different levels of development. In this paper we need to evaluate the competitiveness of the EU member states, thus working with a much more homogenous group of countries. We include gross domestic expenditure on research and development (GERD) as an indicator of S\&T inputs, the quantity of articles in the scientific journals and the quantity of patent applications registered by the European Patent Office (EPO) as indicators of S\&T outputs. To approximate the level of the ICT infrastructure we use a number of internet users (people, who were connected to internet in the last 12 months) and mobile/fixed telephone subscriptions. Probably more appropriate than a number of 
internet users would be the indicator of the high-speed internet, where Europe is falling behind (European Commission, 2010), yet complete data for this indicator are not available. Individual indicators of technology competitiveness, their units and sources are in Table 1. All the variables are available in annual time series for the time period 2000-2012 (2012 is the last year, where data for all variables are available in the entire EU).

Table 1: The individual indicators of technology competitiveness

\begin{tabular}{lll}
\hline Variable & Unit & Source \\
\hline Gross domestic expenditure on & \% of GDP & Eurostat \\
R\&D & & \\
Patent applications to the EPO & per million inhabitants & Eurostat \\
Articles in scientific journals & per inhabitant in working age (15-64) & ISI Web Of Knowledge, Ameco \\
$\begin{array}{lll}\text { Fixed and mobile telephone } \\
\text { subscriptions }\end{array}$ & per 100 inhabitants & World Bank (WDI) \\
Internet users & per 100 inhabitants & World Bank (WDI) \\
\hline
\end{tabular}

Source: Fagerberg, Knell and Srholec (2004, 2005, 2007), own modification

To assess the convergence or divergence tendency of competitiveness in the European Union, we need to construct the composite competitiveness indicator first. The effect of the individual indicators on the composite indicator is not equal. If the true weights of the individual indicators are not known, we have several possibilities how to set them. One can set equal weights, which are usually not accurate. Other possibility is to use an expert's opinion, however, this suffers from high subjectivity. Thus we decided to estimate the weights of individual indicators with the use of the principal component analysis and factor analysis (as suggested for example by Temple and Johnson, 1998 or Fagerberg, Srholec and Knell, 2007). The methodology of the weights estimation as well as composite indicators construction is described in Nardo et al. (2005). The estimated weights of five individual indicators of technology competitiveness are in Table 2.

Table 2: The estimated weights of the individual indicators

\begin{tabular}{llllll}
\hline Variable & GERD & Patents & Journal articles & $\begin{array}{l}\text { Telephone } \\
\text { subscriptions }\end{array}$ & Internet users \\
\hline Weight & 0.21 & 0.21 & 0.17 & 0.18 & 0.23 \\
\hline
\end{tabular}

Source: own calculations based on Eurostat, Ameco, World Bank, ISI Web of Knowledge

As all the variables are in different units, so when it comes to computing the composite indicator of technology competitiveness, we need to normalize the individual variables first. Normalization will ensure, that any of the indicators will not overweigh others. The composite indicator of technology competitiveness is thereafter computed as a weighted average of all the five normalized variables. We use the min-max normalization method, because as mentioned for example by Rozmahel et al. (2013), it preserves an equal impact of all indicators, as all indicators after the min-max normalization have values between 0 and 1 . All variables are normalized as a panel according to the following formula:

$$
I_{q c}^{t}=\frac{x_{q c}^{t}-\min _{t \in T} \min _{c}\left(x_{q}^{t}\right)}{\max _{t \in T} \max _{c}\left(x_{q}^{t}\right)-\min _{t \in T} \min _{c}\left(x_{q}^{t}\right)},
$$

where $t$ is the year, $c$ is the country and $q$ is the indicator. In this modified version we don't use the minimum/maximum value for one concrete year, however, the minimum/maximum value for the whole dataset and thus the dynamic aspect is retained (which is necessary if we want to deal with the convergence analysis). The final composite indicator can reach the 
values between 0 and 1 . Theoretically 0 would mean, that one country achieved in one concrete year the worst results in all variables and on the contrary 1 would mean, that one country was in one year the best in all the variables of technology competitiveness. In reality the composites indicators are somewhere between 0 and 1 , which signifies, that there is no absolute winner or loser. We can say, that the higher/lower and more close to $1 / 0$ the value of the composite indicator is, the more/less competitive is the economy. Besides, the increasing/decreasing value of the composite indicator means an improving/falling off competitiveness of the country. We are aware of the limitations of such composite indicator constructions and interpretations. If there is any change in the country group or time period, the results are not more in effect and it is necessary to count over all composite indicators.

We apply the cluster analysis as a tool for the evaluation of homogeneity in the European Union. The cluster analysis is not as frequently used for the convergence assessment as beta and sigma convergence methods, nevertheless we can find several studies yet (Boreiko, 2002, Quah and Crowley, 2010 or Rozmahel et al. 2013). Our approach is based on the Euclidean distances and Ward's method, since this choice stresses the similarity among subjects in one cluster and the differences among clusters. As input data for the cluster analysis we will use five variables specified in Table 1, which are normalized with the min-max method first and then weighed with estimated weights (see Table 2). If we want to analyze the convergence or divergence of technology competitiveness in the European Union with the use of the cluster analysis, it is necessary to carry out the cluster analysis for all years from the selected time period 2000-2012 and compare the similarity among the countries in individual years. In this respect it is useful to compare the development of the maximum and average distance among clusters in the time period 2000-2012 and also the standard deviation of the distances. From the decline of these indicators in time, we can conclude the increasing homogeneity in the EU and thus the tendency to converge. And otherwise, when the average/maximum distance and standard deviation increase, we can conclude, that EU economies tend to diverge in technology competitiveness.

The commonly used methods of the convergence analysis are the beta and sigma convergence methods (for example Sala-i-Martin, 1996, Young et al., 2008, Žd'árek, 2011 or Mazurek, 2013), which we apply to verify the results of the cluster analysis. The beta convergence method is based on the comparison of the indicator value in the base year and its average growth. If the relationship between the average growth and the value of the indicator in the base year is negative, we can refer to beta convergence. The beta convergence methodology is described by Baumol (1986), Barro and Sala-i-Martin (1992) or Sala-i-Martin (1996). In this contribution we estimate the following equation:

$$
\frac{1}{T} \cdot \ln \left(\frac{y_{i, t 0+T}}{y_{i, t 0}}\right)=\alpha+\beta \cdot \ln \left(y_{i, t 0}\right)+\varepsilon_{i},
$$

where $y_{i, t 0}$ is the value of the indicator in the country $i$ in the base year $t_{0}$ and $y_{i, t 0+T}$ is the value of the indicator in the country $i$ in the last year $\left(t_{0}+T\right)$. If a parameter $\beta$ is negative, than beta convergence is confirmed and contrariwise a positive parameter $\beta$ means beta divergence.

The sigma convergence is defined as the decrease in the variance of the logarithm of the selected indicator among economies in time (Slavík, 2007). The sigma convergence verification is usually based on the standard deviation $(\sigma)$ development:

$$
\sigma_{t}=\sqrt{\frac{1}{N} \sum_{i=1}^{N}\left(\ln y_{i, t}-\mu_{t}\right)^{2}},
$$


where $N$ is the number of economies, $t$ is the year and $\mu_{\mathrm{t}}$ is the average of the logarithmed variable for the whole country group (Young et al., 2008). If $\sigma_{t}>\sigma_{t+1}$, we can refer to sigma convergence and contrariwise if $\sigma_{\mathrm{t}}<\sigma_{\mathrm{t}+1}$, it signifies sigma divergence.

\section{Results}

To evaluate and compare the technology competitiveness development in the European Union it is necessary to compute the composite indicator based on five individual variables described in Table 1. The results of the composite indicator for the first and the last year of the time period 2000-2012 are in Figure 1. The countries are ranged according to their value of the composite indicator in 2000.

Figure 1: The composite indicator of technology competitiveness

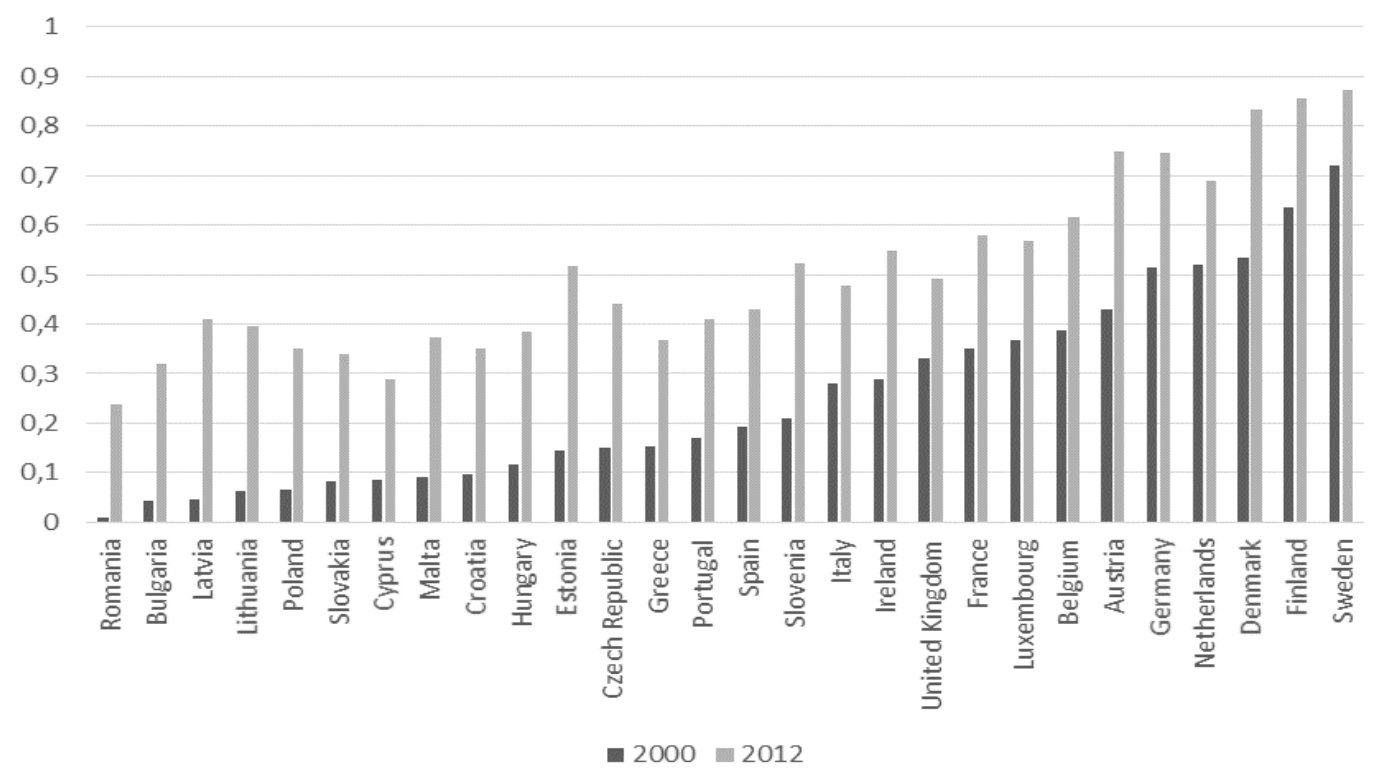

Source: own calculations based on Eurostat, Ameco, World Bank, ISI Web of Knowledge

In 2000 Romania was the least competitive country in a sense of the ability to innovate and although its competitiveness grew, in 2012 Romania with the lowest technology competitiveness still finished in last place. In the base year were all economies, which were not EU member states, at the bottom; with the exception of Slovenia, as it overtook Greece, Portugal and Spain in this year. The most competitive countries in 2000 were Nordic countries, which sustained their leading position till 2012. As we can see, the composite indictor of technology competitiveness grew in all EU economies in the time period 20002012, however, in some countries competitiveness grew faster than in others. The most dynamic growth is apparent in Baltic countries, where the absolute growth of the composite indicator is the biggest one, and thus Latvia, Lithuania and Estonia moved ahead in the ranking. Estonia was in 2012 the twelfth most competitive EU economy and Slovenia was even by one position better.

In the year 2000 the countries were ranked according to the EU membership, all EU members were more competitive than the non-members states (with the exception of Slovenia). In 2012 this is not true anymore, some of the new EU member states (i.e. countries, which entered the EU in 2004 and later) improved their technology competitiveness rapidly and overtook the least competitive old EU member states. In this sense Estonia, Slovenia but also the Czech 
Republic are the winners and Greece, Portugal and Spain the losers. As the absolute differences in the composite indicator of technology competitiveness in 2012 are smaller than in 2000, Figure 1 testifies about the increasing homogeneity in the European Union in the time period 2000-2012. To increase the robustness of these results we thereinafter apply the cluster analysis and beta/sigma convergence model.

\section{The cluster analysis results}

In Figure 2 we can see the development of the average distance and standard deviation of the measured distances among clusters. The standard deviation of measured distances among the clusters decreases, which confirms the increasing homogeneity and thus a tendency to converge among the EU economies. The average distance is rather volatile and experienced an increasing trend, but then again the results are statistically insignificant and the determination coefficient low, thus it cannot imply the increasing heterogeneity in the EU. As far as the maximum distance is concerned, we can see in Figure 3, that it has a decreasing tendency. Thus we can conclude, that the differences in technology competitiveness in the European Union decrease slowly as well as the competitiveness converge.

Figure 2: Development of the standard deviation and average distance among clusters

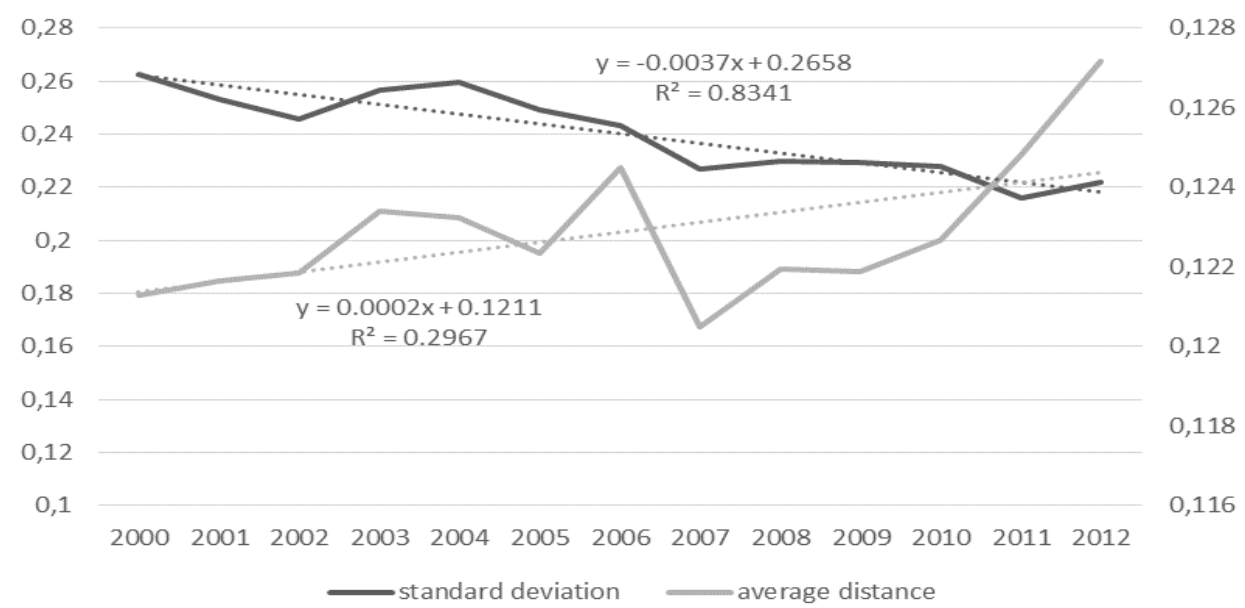

Source: own calculations based on Eurostat, Ameco, World Bank, ISI Web of Knowledge

The next step is to identify the group of countries, which contribute to the increasing homogeneity or contrariwise which create a convergence barrier in the European Union. According to the cluster analysis results we chose four groups of countries, in which we verify the dissimilarities development. These groups are the EU-15 (which consist of 15 original EU member states), the EU-13 (13 new member states, which enter the EU in 2004, 2007 and 2013), the EU-11 (11 original member states, without Greece, Italy, Spain and Portugal, because the south European countries lose their competitive ability during the time period) and the EU-6 (Sweden, Denmark, Finland, Germany, Austria and Netherlands, which are the only six countries belonging to the most competitive cluster during the whole time period 2000-2012). In Figure 3 we can see the development of the maximum distance, the average distance and the standard deviation of distances among clusters in the time period 2000-2012 for the four groups mentioned above and the whole EU.

In the first chart of Figure 3 there is the development of the maximum distance displayed. The biggest dissimilarities are in the EU as a whole, which is expectable. Also the EU-15 group is quite heterogeneous, as the maximum distance is high and have rather slightly growing 
tendency. The lowest differences are among EU-6 countries, because it is the smallest group of the most competitive economies. But also the EU-13 group is according to the maximum distance homogeneous with no outlying observations. The second chart displays the development of the average distance among countries in the group. The EU-13 is the most homogeneous group, but the average distance among new member states is increasing and so does the heterogeneity in this group. This is probably caused by relatively slow competitiveness growth in Bulgaria, Romania and Cyprus. The dissimilarities among EU-6 countries are decreasing; otherwise there is no evidence of the converging trend in this chart. As far as the standard deviation is concerned (the last chart), here the development is mostly stable and thus it does not point out any trend to converge or diverge in the EU. It is worth noting, that standard deviation shows the noticeable dissimilarities in the EU-15, which are to a huge extent caused by South European countries, i.e. Greece, Italy, Spain and Portugal. When we leave out these countries, the EU-11 is much more homogenous.

Figure 3: The maximum distance, average distance and standard deviation of clusters for different groups of countries in 2000-2012
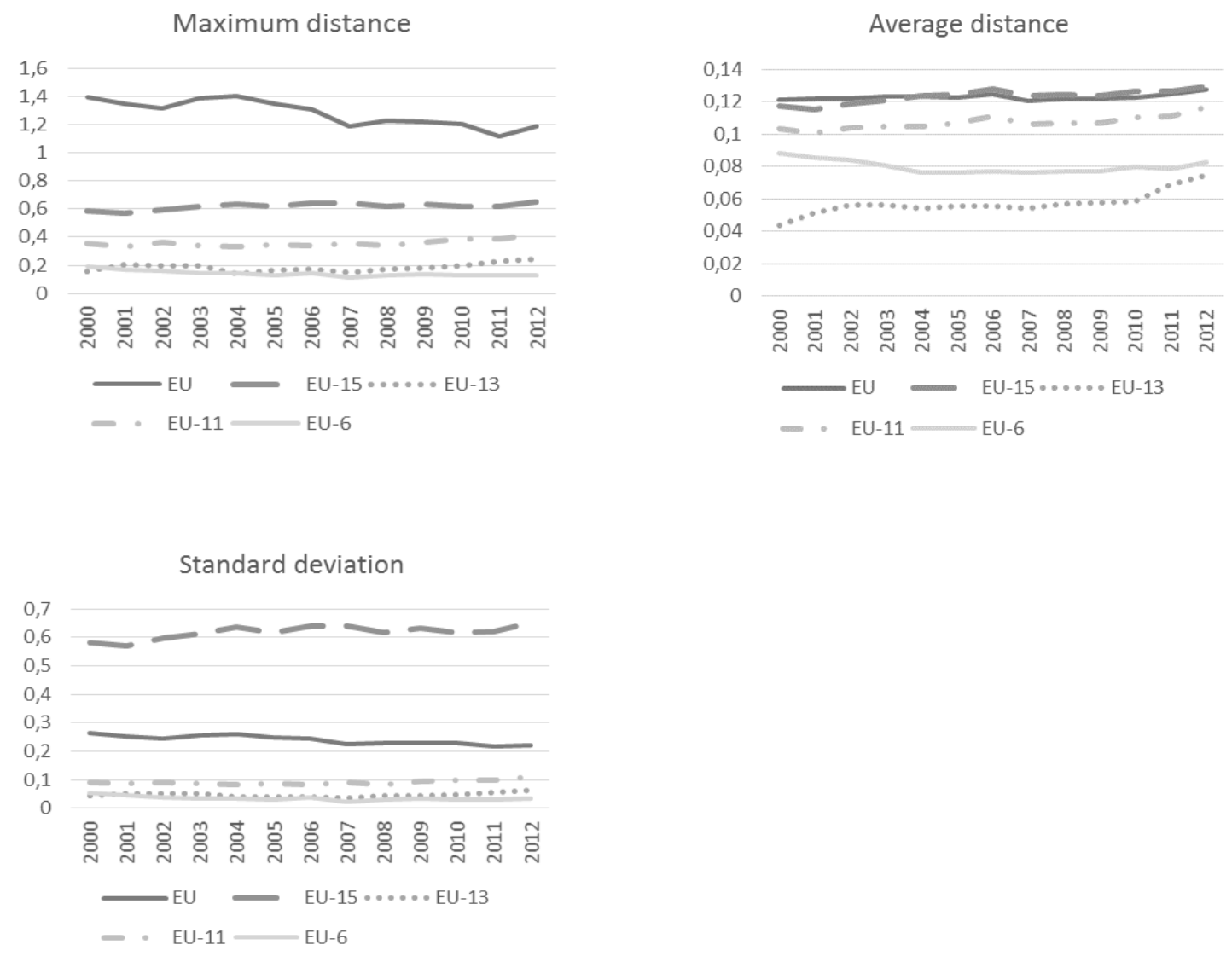

Source: own calculations based on Eurostat, Ameco, World Bank, ISI Web of Knowledge

\section{Beta and sigma convergence results}

The results of the beta convergence model are shown in Table 3. As we can see, the beta coefficient is negative and statistically significant at the $1 \%$ significance level, the model is statistically significant as well, the determination coefficient is high and the normal distribution of residuum and homoscedasticity were proved. Thus we can confirm the beta convergence of technology competitiveness in the European Union. The economies, which 
were in the base year 2000 less competitive, improved their competitiveness more dynamically than initially more competitive countries. The differences among individual EU economies are decreasing slowly as far as their ability to innovate is concerned.

Table 3: The beta convergence model results

\begin{tabular}{|c|c|c|c|c|}
\hline & coefficient & stand.error & t-ratio & p-value \\
\hline constant & $-0,017$ & 0,005 & $-3,462$ & 0,002 \\
\hline TK_2000 & $-0,058$ & 0,002 & $-24,419$ & $<0,00001$ \\
\hline \multicolumn{2}{|c|}{ Determination coefficient } & \multicolumn{2}{|c|}{0,958} & \\
\hline \multicolumn{2}{|c|}{ p-value (F-test) } & \multicolumn{2}{|c|}{$<0,00001$} & \\
\hline \multicolumn{2}{|c|}{ p-value (White test) } & \multicolumn{2}{|c|}{0,220} & \\
\hline \multicolumn{2}{|c|}{ p-value (Jargue-Bera test) } & \multicolumn{2}{|c|}{0,775} & \\
\hline
\end{tabular}

Source: own calculations based on Eurostat, Ameco, World Bank, ISI Web of Knowledge

Previous results of the beta convergence model proved, that there is a catching-up tendency in the European Union, as initially less competitive economies improve their competitiveness faster and thus are catching up initially more competitive countries. The last used concept of the convergence analysis verifies, whether the variance of the indicator in the selected group of countries decreases or increases. The next figure, Figure 4, provides an answer to this question. We can see the standard deviation development for the group of the EU economies in the time period 2000-2012. Apparently the development trend is decreasing which indicates sigma convergence among the EU countries in the selected time period. The statistical testing of the time trend proved the statistical significance both of the time trend and the model at a $1 \%$ significance level. There are no aberrations in the standard deviation development; we can just see the slowdown of the converging trend since 2007.

Figure 4: The sigma convergence model results

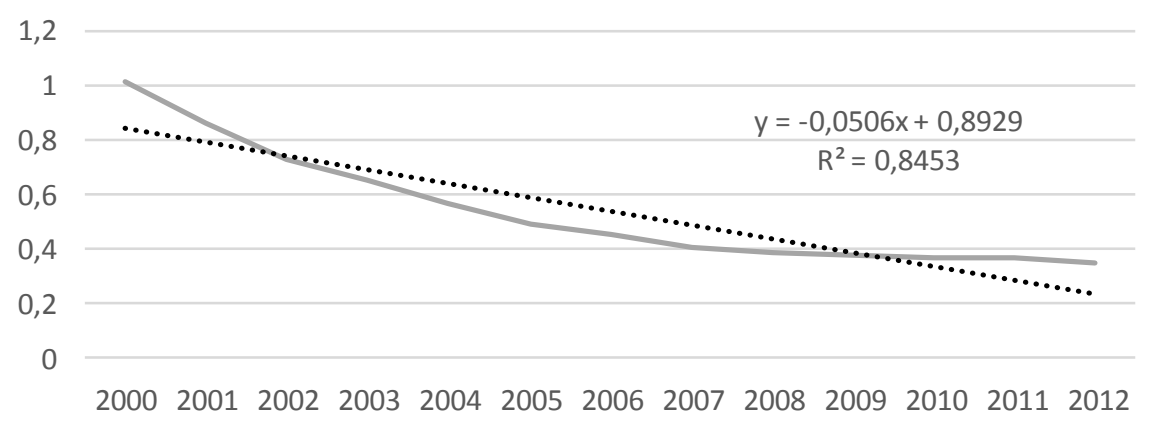

Source: own calculations based on Eurostat, Ameco, World Bank, ISI Web of Knowledge

\section{Conclusion}

The main goal of the contribution was to verify, whether competitiveness in the European Union tends to converge or diverge. We used the composite indicator of technology competitiveness for the competitiveness evaluation, which covers five individual indicators describing the ability to create innovations in the EU economies. We did not find any divergence evidence of technology competitiveness in the European Union in the years 20002012. The opposite trend, i.e. a trend to converge, was confirmed. We applied primarily the method of the cluster analysis in its dynamic form, as we need to compare the similarities development in time. For this comparison we used the maximum/average distance and standard deviation. The declining maximum distance points out to the increasing homogeneity in the European Union as well as the decreasing standard deviation. 
We can identify several barriers of competitiveness convergence in the European Union. Firstly, although the maximum distance decreases, there is still a big difference in technology competitiveness among new and old member states. The second problem is South Europe, especially Spain, Portugal and Greece, which causes noticeable and further increasing heterogeneity among the old EU member states. The most homogeneous group of countries in the EU are 13 new member states (entry to the EU in 2004 and later on), but this is most likely not sustainable and we can expect rather a diverging tendency in this group for the future. We can see, that some of these economies improve their competitive position dynamically (this is especially true for Slovenia and Baltic countries), but some other stagnate or experience just slow growth (Romania or Cyprus).

The results regarding the converging tendency of technology competitiveness in the European Union were confirmed by the beta and sigma convergence methods. The beta convergence model showed, that initially less competitive economies increase their competitive ability faster than initially more competitive countries. So we testified a catching up tendency in the European Union, although it is rather slow and imperceptible. Besides, the decreasing standard deviation confirmed sigma convergence in the whole time period as well.

There is one more important conclusion of our analysis. The results of the cluster analysis and the comparison of its results for individual years point out the increasing homogeneity of the European Union. The same holds true for the beta and sigma convergence results. Nonetheless these results do not show, whether technology competitiveness in the EU member states grows, which is definitely important for an increasing competitiveness of the $\mathrm{EU}$ as a whole. As we can see from the comparison of the composite indicator in the first and last year of the monitored time period, the competitiveness of all EU economies increased. Thus we can conclude, that initially less competitive countries improve their ability to innovate faster and are catching up initially more innovatively efficient countries. At the same time the ability to innovate become better in all EU economies and thus technology competitiveness of the European Union as a whole increase in comparison with other world economies.

To preserve the established convergence trend for the future, less competitive economies should especially focus on gross domestic expenditure on research and development, where the biggest gap among the EU member states is apparent. And what is more, increasing gross domestic expenditure on research and development is one of the priorities introduced by the European Commission for this decade. Despite the significant dissimilarities among the EU economies in the area of the ICT infrastructure (in both internet users and telephone subscriptions) in the base year, it was showed that the new member states caught up with the rest of the European Union and in 2012 the differences among individual countries were negligible. For the future competitiveness growth in the European Union it is necessary to concentrate on the high speed internet expansion, which is the common failure of almost all EU economies.

\section{Literature}

[1] Ameco. Database [online]. [cit. 20th July 2015]. Available at: ec.europa.eu/economy_finance/ameco/user/serie/SelectSerie.cfm

[2] BARBOSA, J. R. and R. H. ALVES, 2011. Divergent Competitiveness in the Eurozone and the Optimum Currency Area Theory [online]. FEP Working Papers No. 436 [cit. 
10th October 2015]. Available at: www.fep.up.pt/investigacao/workingpapers 111.11.02_wp436.pdf

[3] BARRO, R. J. and X. SALA-I-MARTIN, 1992. Convergence. Journal of Political Economy [online]. 100(2), 223-251 [cit. 10th January 2016]. ISSN 0022-3808. Available at: www.jstor.org

[4] BAUMOL, W. J., 1986. Productivity Growth, Convergence, and Welfare: What the Long-Run Data Show. The American Economic Review [online]. 76(5), 1072-1085 [cit. 10th January 2016]. ISSN 0002-8282. Available at: www.jstor.org

[5] BOREIKO, D., 2002. EMU and Accession Countries: Fuzzy Cluster Analysis of Membership [online]. Working paper 71. Oesterreichische Nationalbank [cit. 10th October 2015]. Available at: www.oenb.co.at/workpaper/pubwork.htm

[6] BRUNET, F., 2013. Convergence and Divergences in the European Economy: Rebalancing and Being Competitive in a Non-optimal Monetary Union. Documento de Trabajo, 2013(03), 38. ISSN 2172-7856.

[7] DE GRAUWE, P. and G. SCHNABL, 2005. Nominal Versus Real Convergence - EMU Entry Scenarios for the New Member States. International Review for Social Sciences, 58(4), 537-555. Kyklos. ISSN 2309-0081.

[8] DOBRINSKY, R. and P. HAVLIK, 2014. Economic Convergence and Structural Change: the Role of Transition and EU Accession [online]. wiiw Research report 395. The Vienna Institute for International Economic Studies [cit. 15th October 2015]. Available at: wiiw.ac.at/economic-convergence-and-structural-change-the-role-oftransition-and-eu-accession-dlp-3357.pdf

[9] DOSTÁlOVÁ, I., 2014. Nový institucionální rámec eurozóny: větší důraz na konkurenceschopnost. Scientia et Societas, 2(14), 27-33. ISSN 1801-7118.

[10] ECB, 2015. Real convergence in the euro area: evidence, theory and policy implications. ECB Economic Bulletin [online]. 2015(5), 30-45 [cit. 19th January 2016]. ISSN 23633417. Available at: www.ecb.europa.eu/pub/pdf/other/eb201505_article01.en.pdf

[11] ESTRADA, A., J. GALÍ and D. LÓPEZ-SALIDO, 2012. Patterns of Convergence and Divergence in the Euro Area. In: IMF, 13th Jacques Polak Annual Research Conference [online]. Washington: International Monetary Fund [cit. 12th October 2015]. Available at: www.imf.org/external/np/res/seminars/2012/arc/pdf/ELS.pdf

[12] EUROPEAN COMMISSION, 2010. EUROPE 2020: A European strategy for smart, sustainable and inclusive growth [online]. [cit. 5th July 2015]. Available at: ec.europa.eu/eu2020/pdf/COMPLET\%20EN\%20BARROSO\%20\%20\%20007\%20$\%$ 20Europe\%202020\%20-\%20EN\%20version.pdf

[13] Eurostat. Database [online]. [cit. 20th July 2015]. Available at: ec.europa.eu/eurostat/data/database

[14] FAGERBERG, J., M. KNELL and M. SRHOLEC, 2004. The Competitiveness of nations: Economic growth in the ECE Region [online]. [cit. 5th July 2015]. Available at: folk.uio.no/janf/downloadable_papers/040329_UNECE_FagerbergKnellSrholec_Survey Version.pdf

[15] FAGERBERG, J., M. KNELL and M. SRHOLEC, 2005. The Competitiveness of nations. In: DRUID Tenth Anniversary Summer Conference [online]. Copenhagen. [cit. 5th July 2015]. Available at: www.druid.dk/uploads/tx_picturedb/ds2005-1558.pdf 
[16] FAGERBERG, J., M. KNELL and M. SRHOLEC, 2007. The Competitiveness of Nations: Why some countries prosper while others fall behind. World Development [online]. 35(10), 1595-1620 [cit. 5th July 2015]. ISSN 0305-750X. Available at: ideas.repec.org/a/eee/wdevel/v35y2007i10p1595-1620.html

[17] GROLL, D. and B. VAN ROYE, 2011. Price Competitiveness Divergence in the Euro Area: The Level Matters! Kiel Policy Brief, 24. ISSN 2195-7525.

[18] HALMAI, P. and V. VÁSÁRY, 2010. Real convergence in the new Member States of the European Union (Shorter and longer term prospects). The European Journal of Comparative Economics [online]. 7(1), 229-253 [cit. 25th January 2016]. ISSN 18242979. Available at: eaces.liuc.it/18242979201001/182429792010070110.pdf

[19] HEIN, E. and A. TRUGER, 2002. European monetary union: Nominal convergence, real divergence and slow growth? (An investigation into the effects of changing macroeconomic policy institutions associated with monetary union) [online]. WSI Discussion Paper No. 107 [cit. 25th January 2016]. Available at: www.boeckler.de/pdf/p_wsi_diskp_107.pdf

[20] ISI Web of Knowledge. Number of articles [online]. [cit. 20th July 2015]. Available at: webofknowledge.com

[21] MALÝ, J., 2014. Rozdíly v konkurenceschopnosti mezi státy EU: důsledky pro soudržnost Evropské unie a eurozóny. Scientia et Societas, 2(14), 3-16. ISSN 1801-7118.

[22] MARELLI, E. and M. SIGNORELLI, 2010. Institutional, nominal and real convergence in Europe. Banks and bank systems [online]. 5(2), 140-155 [cit. 20th July 2015]. ISSN 1991-7074. Available at: businessperspectives.org/journals_free/bbs/2010/ BBS_en_2010_2(cont.)_Marelli.pdf

[23] MARTíN, C., F. J. VELÁZQUEZ and B. FUNCK, 2001. European integration and income convergence: Lessons for Central and Eastern European countries. CERGE-EI [online]. [cit. 20th January 2016]. Available at: www.cergeei.cz/pdf/events/papers/020520_t.pdf

[24] MAZUREK, J., 2013. On beta and sigma convergence of Czech regions [online]. MRPA Paper No. 47940 [cit. 20th January 2016]. Available at: mpra.ub.unimuenchen.de/47940/

[25] NARDO, M., M. SAISANA, A. SALTELLI, S. TARANTOLA, A. HOFFMAN and E. GIOVANNINI, 2005. Handbook on Constructing Composite Indicators: Methodology and user guide [online]. OECD Statistics Working Paper 2005/03 [cit. 25th June 2015]. ISSN 1815-2031. Available at: www.oecdilibrary.org/ docserver/download/5lgmz9dkcdg4.pdf?expires=1445497683\&id=id\&accname=guest\&c hecksum=93601BCF4920FC2D246E3A977F982F63

[26] QUAH, CH. H. and P. M. CROWLEY, 2010. Monetary Integration in East Asia: A Hierarchical Clustering Approach. International Finance, 13(2), 283-309. ISSN 14682362.

[27] ROZMAHEL, P., L. KOUBA, L. GROCHOVÁ and N. NAJMAN, 2013. Integration of Central and Eastern European Countries: Increasing EU Heterogeneity? [online]. WWW for Europe, Working Paper No. 9. Available at: www.foreurope.eu/fileadmin/documents/pdf/Workingpapers/WWWforEurope_WPS_no 009_MS77.pdf 
[28] SALA-I-MARTIN, X., 1996. The Classical Approach to Convergence Analysis. The Economic Journal [online]. 106(437), 1019-1036 [cit. 25th June 2015]. ISSN 1468-0297. Available at: www.jstor.org

[29] SLAVÍK, C., 2007. Reálná konvergence České republiky k Evropské unii v porovnání s ostatními novými členskými zeměmi. Politická ekonomie [online]. 55(1), 23-40 [cit. 22nd January 2016]. ISSN 2336-8225. Available at: www.vse.cz/polek/cislo.php?cislo $=4 \&$ rocnik $=2011$

[30] TEMPLE, J. and P. A. JOHNSON, 1998. Social capability and Economic growth. The Quarterly Journal of Economics [online]. 113(3), 965-990 [cit. 12th October 2015]. ISSN 1531-4650. Available at: www.jstor.org/stable/2586879

[31] THE WORLD BANK. World development indicators [online]. [cit. 20th July 2015]. Available at: data.worldbank.org/data-catalog/world-development-indicators

[32] YOUNG, A. T., M. J. HIGGINS and D. LEVY, 2008. Sigma Convergence versus Beta Convergence: Evidence from U.S. County-Level Data. Journal of Money, Credit and Banking [online]. 40(5), 1083-1093 [cit. 25th August 2015]. ISSN 1538-4616. Available at: www.biu.ac.il/soc/ec/d_levy/wp/jmcb5.pdf

[33] ŽĎÁREK, V. and J. ŠINDEL, 2007. Real and nominal convergence and the new EU member states - Actual state and implications. Prague economic papers [online]. 16(3), 195-219 [cit. 22nd January 2016]. ISSN 1210-0455. Available at: www.vse.cz/pep/305

[34] ŽĎÁREK, V., 2011. Empirická analýza průběhu cenové konvergence ČR a nových členských zemí EU k eurozóně. Politická ekonomie [online]. 59(4), 454-474 [cit. 22nd January 2016]. ISSN 2336-8225. www.vse.cz/polek/download.php?jnl=polek\&pdf=799.pdf 